\title{
Analysis of CYP17, CYP19 and CYP1A1 Gene Polymorphisms in Iranian Women with Breast Cancer
}

\author{
Farah Farzaneh$_{4}^{1}$, Giti Noghabaei ${ }^{2}$ *, Esmat Barouti , Farkhondeh Pouresmaili ${ }_{3}^{3}$, \\ Javad Jamshidi ${ }_{3}$ Atena Fazeli, Shaghayegh Taghavi , Babak Emamalizadeh ${ }^{3}$, \\ Hossein Darvish *
}

\begin{abstract}
Breast cancer (BC) is the most common cancer and the second cause of mortality in women all around the world. It is caused by several factors including genetic determinants, so that both genetic susceptibility factors and environmental factors are involved in the etiology. Significance of genes functioning in steroid hormone synthesis and metabolism are well established in breast cancer susceptibility. In this study, 134 women with BC and 135 normal controls were analyzed for their genotypes for the polymorphisms, rs743572, rs10046 and rs4646903, resided in CYP17, CYP19 and CYP1A1 genes, respectively. Significant differences in distributions of allele and genotype frequencies were found for the rs10046 polymorphism in CYP19 (p-value=0.01, OR (CI 95\%) $=1.59(1.1-2.3)$, p-value=0.04, OR (CI 95\%) $=1.7$ (1.1-2.5) respectively). For rs743,572 and rs 4646903 polymorphisms, no significant associations were observed. A significant association was observed between the rs 10046 polymorphism of the CYP19gene and breast cancer in Iranian patients. Due to inconsistent previous results, more studies in different populations with larger sample sizes are indicated.
\end{abstract}

Keywords: Breast cancer - risk factors - gene polymorphisms - CYP17 - CYP19 - CYP1A1

Asian Pac J Cancer Prev, 17, Cancer Control in Western Asia Special Issue, 23-26

\section{Introduction}

Breast cancer $(\mathrm{BC})$ is the most common cancer type in women accounted for one third of all cancer cases. Despite being the second most common cause of mortality in women following the lung cancer, the breast cancer could have a good prognosis by correct management of the disease (McCullough et al., 2014). Several factors are involved in the development of breast cancer including advanced age, family history, radiation therapy in young age, history of pregnancy and breast-feeding and hormone therapy (Enger et al., 1997). Less than 1\% of breast cancer cases arise before 25 years of age but after 30 , the incidence increases significantly and also increases with advancing the age (Jemal et al., 2009). Although the peak age of the onset for breast cancer is between 6th and 7th decades of the life worldwide, in Iranian population it seems that it is between 40 and 60 years of age (Naghavi et al., 2009). Most of the breast cancer cases are sporadic, however, a significant proportion are due to inheritance of particular genetic factors including mutations in specific genes (Fry-Johnson and Rowley, 2010). Studies have demonstrated the 20 to 30 percent of genetic involvement in the etiology of breast cancer (Eccles and Pichert, 2005). Several genes have been identified to be related with increased risk of breast cancer including BRIPI, CHEK2, TGFB, MDM, TP53, PTEN, BRCA2, and BRCA1, and also several polymorphisms in many different genes have been claimed to be associated with the risk of BC (Eccles and Pichert, 2005). It is well established that the lifetime presence of the estrogen in the blood is one of the important risk factors for breast cancer, and this is in consistence with the low incidence of the breast cancer in males that is due to the lower estrogen levels and lower breast tissue volume (Sattin et al., 1986; Wu et al., 2006). In addition, evidences are found regarding the positive role of cell surface receptors of estrogen and progesterone in tumorigenesis (Sattin et al., 1986). Several genes have been found to be involved in synthesis, function, metabolism and secretion of the steroid hormones that one of the most important of them is the P450 family. Among genes of this family, CYP17, CYP19 and CYP1A1 have important functions in synthesis, metabolism and maintaining the levels of the androgen and estrogen hormones, located on10q24.3, 15q21.2 and 15.q24.1 respectively (Bugano et al., 2008).

${ }^{1}$ Infertility and Reproductive Health Research Centre (IRHRC), ${ }^{2}$ Preventive Gynecology Research Centre (PGRC), ${ }^{3}$ Department of Medical Genetics, SchoolofMedicine, ShahidBeheshti University of Medical Sciences, Tehran, ${ }^{4}$ Noncommunicable Diseases Research Center, Fasa University of Medical Sciences, Fasa, Iran*For correspondence: Gitinoghabaei@gmail.com, darvishmg@sbmu.ac.ir 
Several polymorphisms of these genes have been studied and found to be associated with the risk of breast cancer (Shimada and Fujii-Kuriyama, 2004; Zhang et al., 2009). In this study we investigated the association between three polymorphisms, rs743,572, rs10,046 and rs4,646,903, in CYP17, CYP19 and CYP1A1, respectively, in Iranian patients with breast cancer.

\section{Materials and methods}

\section{Subjects}

A total of 269 women were selected including 134 patients with breast cancer and 135 healthy controls. Controls were selected among women who came to the clinic just for checkup, with normal breast exam and normal breast imaging (ultrasonography or mammography only if more than 40 years old). The cases were recruited based on their breast histology report. The two groups were matched for age at onset, puberty and menopause, number of children, age at first pregnancy and BMI. The informed consent was obtained from all participants in the study.

\section{DNA extraction and genotyping}

Genomic DNA was extracted from peripheral blood by standard salting out method. rs743,572 and rs4,646,903 polymorphisms were genotyped using PCR-RFLP method both using MspI restriction enzyme, and rs10,046 polymorphism was genotyped by tetra-primer ARMS method. For PCR-RFLP, the PCR products were digested with MspI restriction enzyme overnight in $37^{\circ} \mathrm{C}$ and then the digestion products were electrophoresed on $2 \%$ agarose gel staining with ethidium bromide. For

Table 1. Demographic Data and Clinical Characteristics

\begin{tabular}{lccc}
\hline & Case & Control & p-value \\
\hline Age & 52.4 & 52.5 & 0.18 \\
Age of puberty & 12.7 & 12.4 & 0.03 \\
Age of menopause & $(\mathrm{n}=71) 50.2$ & $52(\mathrm{n}=81)$ & 0.57 \\
Number of children & 3.7 & 3.0 & 0.03 \\
BMI & 28.2 & 27.5 & 0.22 \\
\hline
\end{tabular}

tetra-primer ARMS, the products of PCR reaction were resolved on 3\% agarose gel. For each polymorphism, 50 samples were randomly selected and sequenced to confirm the obtained data.

\section{Statistical Analysis}

To compare the genotype and allele frequencies difference between the two groups, Pearson's $\chi 2$-tests were applied. A p-value less than 0.05 (two-tailed) was considered to be statistically significant. Deviation from the Hardy-Weinberg equilibrium was tested using Fisher's exact test. We also analyzed the distribution of genotype frequencies under three different genetic models (log-additive, recessive and dominant) using SNPassoc package of R version 3.2 (Gonzalez et al., 2007). All other statistical analysis was also performed using $\mathrm{R}$ version 3.2.0.

\section{Results}

In this study, 269 subjects including 134 patients with breast cancer and 135 healthy controls were recruited to investigate the association of rs74,3572 in CYP17, rs10,046 in CYP19and rs4,646,903 in CYP1A1gene and breast cancer. The demographic data of participants are summarized in table1. There was no evidence of deviation from Hardy-Weinberg equilibrium in any of studied polymorphisms in the population.

The genotypes and allele frequencies were significantly different between case and control groups for rs10,046 of CYP19 gene, so that the TT genotype $(\mathrm{p}$-value $=0.04, \mathrm{OR}(\mathrm{CI} 95 \%)=1.7(1.1-2.5))$ and the $\mathrm{T}$ allele $(\mathrm{p}$-value $=0.01$, OR $(\mathrm{CI} 95 \%)=1.6(1.1-2.3))$ were both significantly higher in patients compared to controls. There was no significant difference between case and control groups in genotypes and allele frequencies for the two other studied SNPs (Table 2). Analyzing the genotype frequencies under different genetic models revealed the significant association of rs 10,046 polymorphism under all the three genetic models but not for the other SNPs (Table 3).

Table 2. Distribution of Genotype and Allele Frequencies for Different SNPs

\begin{tabular}{|c|c|c|c|c|c|c|c|c|c|}
\hline \multirow[b]{2}{*}{ SNP } & \multirow{2}{*}{ Subjects } & \multicolumn{3}{|c|}{ Genotype frequencies s(\%) } & \multirow[t]{2}{*}{$\mathrm{p}$-value } & \multicolumn{2}{|c|}{ Allele frequencies (\%) } & \multirow{2}{*}{$\begin{array}{c}\text { OR } \\
(95 \% \mathrm{CI})\end{array}$} & \multirow[b]{2}{*}{$\mathrm{p}$-value } \\
\hline & & $\mathrm{T} / \mathrm{T}$ & $\mathrm{C} / \mathrm{T}$ & $\mathrm{CC}$ & & $\mathrm{T}$ & C & & \\
\hline \multirow[t]{3}{*}{ CYP1A1 } & Case & $34.0(27.4)$ & $69.0(55.6)$ & $21.0(17.0)$ & \multirow{3}{*}{0.8} & $137.0(55.2)$ & $111.0(44.8)$ & & \multirow{3}{*}{0.55} \\
\hline & $(\mathrm{N}=124)$ & & & & & & & 1.1 & \\
\hline & $\begin{array}{l}\text { Control } \\
(\mathrm{N}=100)\end{array}$ & $30.0(30.0)$ & $56.0(56.0)$ & $14.0(14.0)$ & & $116.0(58.0)$ & $84(42.0)$ & $(0.8-1.6)$ & \\
\hline \multirow[t]{3}{*}{ CYP19 } & Case & $33.0(26.6)$ & $68.0(54.8)$ & $23.0(18.6)$ & \multirow{3}{*}{$0.04^{*}$} & $134.0(54.0)$ & $114.0(46.0)$ & \multirow{3}{*}{$\begin{array}{c}1.6 \\
(1.1-2.3)\end{array}$} & \multirow{3}{*}{$0.01^{*}$} \\
\hline & $(\mathrm{N}=124)$ & & & & & & & & \\
\hline & $\begin{array}{c}\text { Control } \\
(\mathrm{N}=100)\end{array}$ & $15.0(15.0)$ & $55.0(55.0)$ & $30.0(30.0)$ & & $85.0(42.5)$ & $115.0(57.5)$ & & \\
\hline \multirow[t]{3}{*}{ CYP17 } & Case & $32.0(25.8)$ & $70.0(56.5)$ & $22.0(17.7)$ & \multirow{3}{*}{0.97} & $134.0(54.0)$ & $114.0(46.0)$ & \multirow{3}{*}{$\begin{array}{r}1.0 \\
(0.7-1.5)\end{array}$} & \multirow{3}{*}{0.8} \\
\hline & $(\mathrm{N}=124)$ & & & & & & & & \\
\hline & $\begin{array}{l}\text { Control } \\
(\mathrm{N}=100)\end{array}$ & $27.0(27.0)$ & $56.0(56.0)$ & $17.0(17.0)$ & & $110.0(55.0)$ & $90.0(45.0)$ & & \\
\hline
\end{tabular}

*considered as significant 
Table 3. Analysis of Genotype Distributions Under Three Genetic Models

\begin{tabular}{|c|c|c|c|c|c|c|}
\hline \multirow[b]{2}{*}{ SNP } & \multicolumn{2}{|c|}{ Additive } & \multicolumn{2}{|c|}{ Recessive } & \multicolumn{2}{|c|}{ Dominant } \\
\hline & $\mathrm{p}$-value & $\begin{array}{c}\text { OR } \\
(95 \% \mathrm{CI}) \\
\end{array}$ & $\mathrm{p}$-value & $\begin{array}{c}\text { OR } \\
(95 \% \mathrm{CI}) \\
\end{array}$ & $\mathrm{p}$-value & $\begin{array}{c}\text { OR } \\
(95 \% \mathrm{CI}) \\
\end{array}$ \\
\hline \multirow{2}{*}{ CYP1A1 } & \multicolumn{2}{|c|}{$(\mathrm{T} / \mathrm{T}=0 \mathrm{C} / \mathrm{T}=1, \mathrm{C} / \mathrm{C}=2)$} & \multicolumn{2}{|c|}{ (C/C vs. $\mathrm{C} / \mathrm{T}+\mathrm{T} / \mathrm{T})$} & \multicolumn{2}{|c|}{ (T/T vs. $\mathrm{C} / \mathrm{T}+\mathrm{C} / \mathrm{C})$} \\
\hline & 0.52 & $\begin{array}{c}1.1 \\
(0.8-1.7)\end{array}$ & 0.54 & $\begin{array}{c}1.3 \\
(0.6-2.6)\end{array}$ & 0.7 & $\begin{array}{c}1.1 \\
(0.6-2.0)\end{array}$ \\
\hline \multirow{2}{*}{ CYP19 } & \multicolumn{2}{|c|}{$(\mathrm{C} / \mathrm{C}=0 \mathrm{C} / \mathrm{T}=1, \mathrm{~T} / \mathrm{T}=2)$} & \multicolumn{2}{|c|}{ (T/T vs. $\mathrm{C} / \mathrm{T}+\mathrm{C} / \mathrm{C})$} & \multicolumn{2}{|c|}{$(\mathrm{C} / \mathrm{C}$ vs. $\mathrm{C} / \mathrm{T}+\mathrm{T} / \mathrm{T})$} \\
\hline & $0.01^{*}$ & $\begin{array}{c}1.7 \\
(1.1-2.5)\end{array}$ & $0.03^{*}$ & $\begin{array}{c}2.1 \\
(1.0-4.1)\end{array}$ & $0.04^{*}$ & $\begin{array}{c}1.9 \\
(1.0-3.5)\end{array}$ \\
\hline \multirow{2}{*}{ CYP17 } & \multicolumn{2}{|c|}{$(\mathrm{T} / \mathrm{T}=0 \mathrm{C} / \mathrm{T}=1, \mathrm{C} / \mathrm{C}=2)$} & \multicolumn{2}{|c|}{$(\mathrm{C} / \mathrm{C}$ vs. $\mathrm{C} / \mathrm{T}+\mathrm{T} / \mathrm{T})$} & \multicolumn{2}{|c|}{ (T/T vs. $\mathrm{C} / \mathrm{T}+\mathrm{C} / \mathrm{C})$} \\
\hline & 0.82 & $\begin{array}{c}1.1 \\
(0.7-1.6)\end{array}$ & 0.88 & $\begin{array}{c}1.1 \\
(0.5-2.1)\end{array}$ & 0.84 & $\begin{array}{c}1.1 \\
(0.6-1.9)\end{array}$ \\
\hline
\end{tabular}

*considered as significant

\section{Discussion}

In this study, 269 subjects including 134 breast cancer patients and 135 normal subjects as control group were analyzed for genotype of three polymorphisms, rs743,572, rs 10,046 and rs4,646,903 in three distinct genes, CYP17, CYP19 and CYP1A1, respectively. Significant associations were observed between rs10,046 polymorphism of CYP19 gene and breast cancer in our subject population. All mentioned polymorphisms have been investigated in several studies and in different populations and different results have been reported. For rs 743,572 polymorphism of the CYP17gene, significant association was found with breast cancer risk in Canadian and Russian populations (Artamonov et al., 2003; Cribb et al., 2011), but in a study on Chinese population, no evidence of association was observed (Han et al., 2005). The rs10,046 polymorphism of the CYP19gene has been also shown inconsistent results, so that no significant association was found in USA and China (Haiman et al., 2002; Zhang et al., 2009), but recent studies in Austria and Xinjiang Uigur found significant differences in distribution of alleles and genotypes between women with breast cancer and normal women (Zins et al., 2014; Yang et al., 2015). Finally, the rs 4646903 polymorphism of the CYP1A1 gene can also found to be investigated in several studies and different populations. Results of association studies for this SNP are similar to other two SNPs and controversial as well. Associations of this polymorphism was proved in African-American population (Taioli et al., 1995), and also in Korean and Chinese populations (Shen et al., 2006; Shin et al., 2007), but Kiruthiga et al (2011) found no specific association of this polymorphism with breast cancer in Indian women.

There is growing evidences for involvement of genetic polymorphisms in complex disorders as they can affect the functions of genes by altering characteristics such as the expression level, altering DNA binding sites, mRNA stabilization, splicing and folding (Jin et al., 1996; Duan et al., 2003; Chen et al., 2006). For the rs10,046 polymorphism of CYP19gene, the exact functional activity is not clearly understood, and it seems not to have an autonomous function, but it has been claimed that in conjunction with other polymorphisms, the rs10,046 polymorphism may influence the levels of mRNA and its stability (Bampali et al., 2015), so it can be associated with altered levels of the aromatase enzyme and affected estrogen metabolism.

In our study, there was significant associations between CYP19rs10046 polymorphism and BC in Iranian women, but no associations were observed with polymorphisms of CYP17and CYP1A1 genes. As can be seen, there is a great inconsistency in results of the different studies and different populations. This contradictory results may be due to several factors such as genetic context of different populations or founder effects. So, it seems necessary to examine the effects of these polymorphisms in different populations.

\section{References}

Artamonov VV, Liubchenko LN, Shabanov MA, et al (2003). [Association of polymorphism of genetic markers of CYP19 and CYP17 with sporadic breast cancer]. Mol Biol (Mosk), 37, 975-82.

Bampali K, Grassos C, Mouzarou A, et al (2015). Genetic variant in the CYP19A1 gene associated with coronary artery disease. Genet Res Int, 25, 820323.

Bugano DD, Conforti-Froes N, Yamaguchi NH, et al (2008). Genetic polymorphisms, the metabolism of estrogens and breast cancer: a review. Eur J Gynaecol Oncol, 29, 313-20.

Chen X, Truong TT, Weaver J, et al (2006). Intronic alterations in BRCA1 and BRCA2: effect on mRNA splicing fidelity and expression. Hum Mutat, 27, 427-35.

Cribb AE, Joy Knight M, Guernsey J, et al (2011). CYP17, catechol-o-methyltransferase, and glutathione transferase M1 genetic polymorphisms, lifestyle factors, and breast cancer risk in women on Prince Edward Island. Breast $J$, 17, 24-31.

Duan J, Wainwright MS, Comeron JM, et al (2003). Synonymous mutations in the human dopamine receptor D2 (DRD2) affect mRNA stability and synthesis of the receptor. Hum Mol Genet, 12, 205-16.

Eccles DM, Pichert G(2005). Familial non-BRCA1//BRCA2-associated breast cancer. Lancet Oncol, 6, 705-11.

Enger SM, Ross RK, Henderson B, et al (1997). Breastfeeding 
Farah Farzaneh et al

history, pregnancy experience and risk of breast cancer. $\mathrm{Br}$ $J$ Cancer, 76, 118-23.

Fry-Johnson YW, Rowley DL (2010). The enigma of spontaneous preterm birth. N Engl J Med, 362, 2032-4.

Gonzalez JR, Armengol L, Sole X, et al (2007). SNPassoc: an $\mathrm{R}$ package to perform whole genome association studies. Bioinformatics, 23, 644-5.

Haiman CA, Hankinson SE, Spiegelman D, et al (2002). No association between a single nucleotide polymorphism in CYP19 and breast cancer risk. Cancer. Epidemiol Biomarkers Prev,11, 215-6.

Han DF, Zhou X, Hu MB, et al (2005). Polymorphisms of estrogen-metabolizing genes and breast cancer risk: a multigenic study. Chin Med J (Engl), 118, 1507-16.

Jemal A, Siegel R, Ward E, et al (2009). Cancer statistics, 2009. CA Cancer J Clin, 59, 225-49.

Jin Y, Dietz HC, Montgomery RA, et al (1996). Glanzmann thrombasthenia. Cooperation between sequence variants in cis during splice site selection. J Clin Invest, $\mathbf{9 8 ,}$ 1745-54.

Kiruthiga PV, Kannan MR, Saraswathi C, et al (2011). CYP1A1 gene polymorphisms: lack of association with breast cancer susceptibility in the southern region (Madurai) of India. Asian Pac J Cancer Prev, 12, 2133-8.

McCullough LE, Santella RM, Cleveland RJ, et al (2014). Polymorphisms in DNA repair genes, recreational physical activity and breast cancer risk. Int $J$ Cancer, 134, 654-63.

Naghavi M, Abolhassani F, Pourmalek F, et al (2009). The burden of disease and injury in Iran 2003. Popul Health Metr, 7, 9-14.

Sattin RW, Rubin G, Wingo PA, et al (1986). Oral-contraceptive use and the risk of breast cancer. The cancer and steroid hormone study of the centers for disease control and the national institute of child health and human development. $N$ Engl J Med, 315, 405-11.

Shen Y, Li DK, Wu J, et al (2006). Joint effects of the CYP1A1 MspI, ERalpha PvuII, and ERalpha XbaI polymorphisms on the risk of breast cancer: results from a population-based case-control study in Shanghai, China. Cancer Epidemiol Biomarkers Prev, 15, 342-7.

Shimada T, Fujii-Kuriyama Y (2004). Metabolic activation of polycyclic aromatic hydrocarbons to carcinogens by cytochromes P450 1A1 and 1B1. Cancer Sci, 95, 1-6.

Shin A, Kang D, Choi JY, et al (2007). Cytochrome P450 1A1 (CYP1A1) polymorphisms and breast cancer risk in Korean women. Exp Mol Med, 39, 361-6.

Taioli E, Trachman J, Chen X, et al (1995). A CYP1A1 restriction fragment length polymorphism is associated with breast cancer in African-American women. Cancer Res, 55, 3757-8.

Wu MH, Chou YC, Yu JC, et al (2006). Hormonal and body-size factors in relation to breast cancer risk: a prospective study of 11,889 women in a low-incidence area. Ann Epidemiol, 16, 223-9.

Yang L, Wang XY, Li YT, et al (2015). CYP19 gene polymorphisms and the susceptibility to breast cancer in Xinjiang Uigur women. Genet Mol Res, 14, 8473-82.

Zhang L, Gu L, Qian B, et al (2009). Association of genetic polymorphisms of ER-alpha and the estradiol-synthesizing enzyme genes CYP17 and CYP19 with breast cancer risk in Chinese women. Breast Cancer Res Treat, 114, 327-38.

Zins K, Mogg M, Schneeberger C, et al (2014). Analysis of the rs 10046 polymorphism of aromatase (CYP19) in premenopausal onset of human breast cancer. Int J Mol Sci, $15,712-24$. 